Подгорная И. А.

I. A. Podgornaya

СООТНОШЕНИЕ СМЫСЛОВ В РЕЛИГИОЗНОМ ЭКФРАСИСЕ (НА ПРИМЕРЕ

РОМАНА Ф. М. ДОСТОЕВСКОГО «ПРЕСТУПЛЕНИЕ И НАКАЗАНИЕ»

И ИЛЛЮСТРАЦИЙ Д. А. ШМАРИНОВА, М. П. КЛОДТА, О. С. ЕВСЕЕВА)

\title{
THE MEANING RATIO IN RELIGIOUS ECPHRASIS (BASED ON DOSTOEVSKY'S «CRIME AND PUNISHMENT» AND GRAPHIC BY D. A. SHMARINOV, M. P. KLODT, O.S. YEVSEYEV)
}

Подгорная Инна Александровна - соискатель Забайкальского государственного университета; преподаватель ГБПОУ КК «Новороссийский социально-педагогический колледж» (Россия, Новороссийск); Россия, Краснодарский край, г. Новороссийск, ул. Мысхакское шоссе, 48, тел. 8(928)2633837. E-mail: podg.inna@yandex.ru.

Ms. Inna A. Podgornaya - applicant, Trans-Baikal State University; lecturer of Novorossiysk social and pedagogical college (Russia, Novorossiysk); Russia, Krasnodar region, Novorossiysk, 48, Myskhakskoye highway, tel. 8(928)2633837. E-mail: podg.inna@yandex.ru.

Аннотация. Статья посвящена анализу смысла словесного текста на тему пьянства в романе Ф. М. Достоевского «Преступление и наказание» на примере образа бражника Мармеладова. Выявляется смысловое соответствие данного словесного текста иллюстрациям русских художников конца XIX - начала XX вв. Д. А. Шмаринова «Мармеладов в распивочной», М. П. Клодта «Раскольников и Мармеладов» и О. С. Евсеева «Раскольников и Мармеладов в распивочной» с точки зрения религиозного экфрасиса. Рассматривается смысловое соотношение между святоотеческим наследием о грехе винопития со словесным текстом романа и его живописной визуализацией в контексте религиозного прочтения.

Summary. This article analyzes the meaning of the verbal text about alcoholism in F. M. Dostoevsky's «Crime and Punishment» illustrated by the image of Marmeladov. The article also reveals semantic correspondence of the verbal text and graphic by Russian artists of the late XIX - early XX centuries, such as D. A. Shmarinov's «Marmeladov in the tavern», M. P Klodt 's «Raskolnikov and Marmeladov» and O. S. Yevseyev's «Raskolnikov and Marmeladov in the tavern» in terms of religious ecphrasis. The author considers the semantic ratio between patristic heritage of drinking wine sin with the verbal text of the novel and its picturesque visualization in the context of a religious reading.

Ключевые слова: экфрасис, смысл, порок чревоугодия, иллюстрации к тексту.

Key words: ecphrasis, meaning, sin of gluttony, graphic to the text.

УДК 008

Современный глобализирующийся мир характеризуется наличием проблем, связанных с духовно-нравственным развитием человека и общества. Потенциал русской культуры содержит пути решения многих современных проблем, в частности проблем, связанных с духовно-нравственным состоянием общества. От решения этих проблем зависит формирование экономической, политической и социокультурной составляющих в существовании любого государства. Актуальность статьи обусловлена необходимостью сопоставления смыслов словесного и живописного текстов, что позволяет приблизиться к пониманию их своеобразия и помогает по-новому интерпретировать исследуемый образ. Целью статьи является выявление смыслового соотношения словесного и живописного текстов в контексте религиозного прочтения. Соотношение смыслов в религиозном экфрасисе в данной статье 
Подпорная И.А.

СООТНОШЕНИЕ СМЫСЛОВ В РЕЛИГИОЗНОМ ЭКФРАСИСЕ (НА ПРИМЕРЕ РОМАНА Ф.М. ДОСТОЕВСКОГО «ПРЕСТУПЛЕНИЕ И НАКАЗАНИЕ» И ИЛЛЮСТРАЦИЙ Д.А. ШМАРИНОВА, М.П. КЛОДТА, О.С. ЕВСЕЕВА)

будет показано на примере словесного описания образа Мармеладова и вложенных в него Ф. М. Достоевским смыслов и иллюстраций художников Д. А. Шмаринова, М. П. Клодта и О. С. Евсеева, которые усиливают художественно эти словесные смыслы Ф. М. Достоевского.

Проблема смысловой интерпретации произведений искусства остаётся значимой на современном этапе развития культурологических исследований. Особенно актуальной сегодня является интерпретация живописи и литературы в рамках вербального текста. Философско-культурологическая мысль разных эпох предлагала способы расшифровки образов живописи и литературы. Сегодня всё чаще звучит призыв к поиску таких моделей смысловой организации текста, которые позволят соединить литературу и живопись, выявив новый смысловой пласт. Современные культурологи реанимировали к жизни такое понятие, как экфрасис, которое и станет ключевым в предлагаемой статье. Исследованию экфрасиса посвящено немного исследований. В статье Е. В. Яценко экфрасис рассматривается «не только как структурно-семантическая единица текста и один из способов его организации, но как модель соединения живописи и литературы, которая является источником порождения новых смыслов - некоего смыслового взрыва» [6, 47].

Так, автор статьи впервые предлагает сопоставительный анализ фрагментов текста на тему пьянства в романе Ф. М. Достоевского «Преступление и наказание» (образ бражника Мармеладова) и соответствующих им иллюстраций русских художников конца XIX - начала ХХ вв. (Д. А. Шмаринова «Мармеладов в распивочной», М. П. Клодта «Раскольников и Мармеладов» и О. С. Евсеева «Раскольников и Мармеладов в распивочной») с точки зрения религиозного экфрасиса.

Экфрасис - это смысловое соотношение слова и живописи, а религиозный экфрасис подразумевает сакральное смысловое соотношение слова и живописи. Понятие «религиозный экфрасис» впервые вводит Л. М. Геллер в статье «Воскрешение понятия, или слово об экфрасисе». Л. М. Геллер рассматривает это понятие более с филологической точки зрения, нежели с богословской и культурологической $[1,5]$. Исследователь определяет экфрастический «религиозный принцип» как «приглашение - побуждение к духовному видению как к высшему восприятию мира и восприятию высшего мира, и вместе с тем - принцип сакрализации художественности как гарантии целостности восприятия» $[1,5]$.

Н. Е. Меднис в статье «Религиозный экфрасис в русской литературе» исследует Богородичный экфрасис как вид религиозного экфрасиса. Н. Е. Меднис анализирует многочисленные художественные тексты на наличие образа Богородицы или Мадонны. Религиозный экфрасис, по мнению Н. Е. Меднис, «удваивает, усиливает ещё и пограничность иного рода предел, грань миров, что, несомненно, сказывается на его эстетических составляющих» $[4,58]$.

Религиозный экфрасис воплощает с помощью смысла словесного текста то, что в живописном тексте воспринимается религиозно настроенным сознанием писателя и читателя/зрителя. Таким образом, религиозный экфрасис - это не только смысловая словесная визуализация живописного текста, но и смысловая живописная визуализация словесного текста в контексте религиозного прочтения. Религиозный экфрасис становится приёмом, с помощью которого можно интерпретировать смысл словесного текста романа Ф. М. Достоевского, сопоставив его с иллюстрациями, раскрывающими образ бражника Мармеладова, и со смыслом текста (учения) преподобного Иоанна Лествичника о страсти пьянства.

После Пятого Вселенского собора (553 г.) преподобный Иоанн Лествичник, игумен Синайского монастыря, создаёт книгу «Лествица, или Скрижали духовные». Данное творение призвано научить человека, как бороться с пороками и страстями, как жить благочестиво и восстановить в душе образ Божий. По поводу пьянства в «Лествице» автор замечает: «Пришествие других чревоугодник считает за предлог, разрешающий пить вино; и ... делается рабом страсти» $[5,150]$. Данные слова проецируются на ситуацию в романе, когда Раскольников входит в распивочную, где находится Мармеладов, который: «упорно смотрел на него [на Раскольникова] и видно было, что ему очень хотелось начать разговор ... Громко и 
твёрдо [Мармеладов] проговорил: “А осмелюсь ли, милостивый государь мой, обратиться к вам с разговором приличным?” ... Наклонность к витиеватой речи приобрёл он, вероятно, вследствие привычки к частым кабачным разговорам с различными незнакомцами. Эта привычка обращается у иных пьющих в потребность» $[3,10]$.

Слова Иоанна Лествичника «пришествие других» как приход, встречу незнакомьхх людей проецируются на словесный текст романа: «Бывают встречи ... с незнакомыми нам людьми, которыми мы начинаем интересоваться с первого взгляда ...» $[3,11]$. Смысл словесного текста Иоанна Лествичника и Ф. М. Достоевского соотносится с иллюстрацией О. С. Евсеева «Раскольников и Мармеладов в распивочной». Художник изображает встречу бражника и Раскольникова, сидящих за столом в распивочной. На интерес с первого взгляда указывает удивлённый взгляд Раскольникова, заинтересованного Мармеладовым.

Смысл слов Иоанна Лествичника «предлог, разрешающий пить вино» соотносится со словесным текстом романа: «А позвольте... - Он [Мармеладов] привстал, покачнулся, захватил свою посудинку, стаканчик, и подсел к молодому человеку ... налил стаканчик, выпил и задумался» [3, 11]. Смысловое соотношение словесных текстов Иоанна Лествичника и Ф. М. Достоевского сопоставляется с иллюстрацией О. С. Евсеева «Раскольников и Мармеладов в распивочной». Художник изображает Мармеладова с поднятой рукой, в которой держит наполненный стаканчик. Такой жест бражника говорит о его намерении опустошить этот стаканчик.

Слова Иоанна Лествичника «делается рабом страсти» соотносятся со смыслом словесного текста романа: «привычка к частым кабачным разговорам ... обращается у иных пьющих в потребность ... на остальных же смотрел он [Мармеладов] как-то привычно» $[3,11]$. В данном случае слово раб страсти находится в соответствии со словами привычка и nотребность. А на иллюстрации М.П. Клодта данные слова Иоанна Лествичника и Ф. М. Достоевского воплощаются в образ Мармеладова, сидящего у стола в распивочной, в расслабленной позе и со спокойным выражением лица, что говорит о привычке к обстановке распивочной. Указанием на слово потребность являются 2 штофа и 2 стакана, стоящие рядом с бражником.

Слово Пятое «О покаянии» в «Лествице» гласит: «Все, а в особенности падшие, должны беречься, чтобы не допустить в сердце своё недуг безбожного Оригена; ибо сквернословное его учение, внушая о Божьем человеколюбии, весьма приятно людям сластолюбивым» $[5,151]$. Необходимо отметить, что еретик Ориген был осуждён на V Вселенском Соборе. В примечании к Слову Пятому говорится, что Иоанн Лествичник указывает на мнение безбожника Оригена, будто все люди, даже «самые нечестивые, претерпевшие долгие муки в геенне огненной», очистятся и будут помилованы Христом [5, 534]. Данная точка зрения проецируется на мнение Мармеладова, который в распивочной говорит Раскольникову о прощении, ожидающем «пьяненьких» в день Страшного суда. Именно в отношении к такому греху, как пьянству - греху позорному и грязному, по мнению Мармеладова, - проявится милосердие Христа. Указанный смысл словесных текстов Иоанна Лествичника и Ф. М. Достоевского сопоставляется с иллюстрациями М. П. Клодта «Раскольников и Мармеладов» и О. С. Евсеева «Раскольников и Мармеладов в распивочной» в виде разговора героев.

Слова Иоанна Лествичника «людям сластолюбивым» соотносятся с фамилией Мармеладов в романе. Винопитие, пьянство является разновидностью греха чревоугодия. В Толковом словаре В. И. Даля слово чревоугодник означает: «Пристрастный к лакомым яствам и напиткам, сластолюбец», а сластолюбец - это «человек, удовлетворяющий чувственные потребности» $[2,608]$. В. И. Даль слову сластный даёт определение «чувственный, сладострастный» $[2,222]$. Можно сделать вывод, что слова сластолюбец, чревоугодник, а соответственно, и пьяница - слова одного смыслового ряда. В данном случае фамилия Мармеладов не случайная, в ней заключено прямое указание на страсть чревоугодия, винопития как сладость, «сластность», сладенький. Смысловое соотношение данных словесных текстов 
Подгорная И.А.

СООТНОШЕНИЕ СМЫСЛОВ В РЕЛИГИОЗНОМ ЭКФРАСИСЕ (НА ПРИМЕРЕ РОМАНА Ф.М. ДОСТОЕВСКОГО «ПРЕСТУПЛЕНИЕ И НАКАЗАНИЕ» И ИЛЛЮСТРАЦИЙ Д.А. ШМАРИНОВА, М.П. КЛОДТА, О.С. ЕВСЕЕВА)

Иоанна Лествичника и Ф. М. Достоевского отражёно на всех трёх исследуемых иллюстрациях (Д. А. Шмаринова «Мармеладов в распивочной», М. П. Клодта «Раскольников и Мармеладов» и О. С. Евсеева «Раскольников и Мармеладов в распивочной») в изображении сластолюбиа Мармеладова, сидящего в распивочной за столом со стаканами и штофом. Эти атрибуты являются указанием на пьянство героя, его чревоугодие.

Сопоставительный анализ позволяет выявить смысловое соотношение двух текстов (словесного и живописного) и увидеть, как смысл словесного текста соотносится с образом на иллюстрациях художников. Произведение живописи предполагает создание определённого образа героя, эстетически освоенного художником [6, 47]. Художник создаёт образ под воздействием на него смысла словесного текста, как текста самого художественного произведения, так и текста собственного, поскольку известно, что замыслы многих картин находили своё первоначальное выражение именно в слове, возникающем в воображении художника.

В современной культурологии религиозный экфрасис используется как приём, позволяющий сопоставить смыслы словесного и живописного текстов и вывести новый смысловой пласт на основе святоотеческого наследия, литературы и живописи. Учение Иоанна Лествичника, словесный текст Ф. М. Достоевского и живописные тексты Д. А. Шмаринова, М. П. Клодта и О. С. Евсеева создают единый смысловой пласт в изображении образа бражника.

Стоит отметить, что особую значимость религиозный экфрасис на тему образа бражника Мармеладова несёт сегодня, когда порок пьянства, чревоугодия предстаёт перед людьми весьма заманчивым явлением, поскольку потеряны границы между добром и злом, грехом и добродетелью.

Культурологическое исследование религиозного экфрасиса образа бражника Мармеладова позволяет глубже проникнуть в семиотику художественного текста, а также увидеть воздействие святоотеческого учения о разрушительной страсти пьянства на создание образа героя в смысловом словесном тексте романа, который, в свою очередь, повлиял на создание иллюстраций, раскрывающих исследуемый образ. Культурологический подход к рассмотрению религиозного экфрасиса позволяет донести до читателя/зрителя смысл святоотеческого наследия через смысл произведения искусства с целью побуждения к духовному мировосприятию и последующему преображению личности. Такое мироощущение человека является основным элементом культурной картины мира, через которую раскрывается духовный смысл греха современному поколению.

\section{ЛИТЕРАТУРА}

1. Геллер, Л. Воскрешение понятия, или слово об экфрасисе / Л. Геллер // Экфрасис в русской литературе: труды Лозаннского симпозиума / под ред. Л. Геллера. - М.: МИК, 2002. - С. 5-22.

2. Даль, В. И. Толковый словарь живого великорусского языка. В 4 т. Т. 4 / В. И. Даль. - СПб.: Издание М. О. Вольфа, 1882. - 714 с.

3. Достоевский, Ф. М. Преступление и наказание / Ф. М. Достоевский. - М.: Славянка, 1993. - 334 с.

4. Меднис, Н. Е. «Религиозный экфрасис» в русской литературе / Н. Е. Меднис // Критика и семиотика. - 2006. - № 10. - С. 58-67.

5. Лествичник, И. Лествица / Иоанн Лествичник. - М.: Сибирская благозвонница, 2013. - 576 с.

6. Яценко, Е. В. «Любите живопись, поэты...»: экфрасис как художественно-мировоззренческая модель / Е. В. Яценко // Вопросы философии. - 2011. - № 11. - С. 47-57. 